University of Michigan Law School

University of Michigan Law School Scholarship Repository

Law \& Economics Working Papers

$12-21-2017$

\title{
Tit for Tat: How Will Other Countries React to the Tax Cuts and Jobs Act?
}

\author{
Reuven S. Avi-Yonah \\ University of Michigan Law School, aviyonah@umich.edu \\ Gianluca Mazzoni \\ University of Michigan Law School, gmazzoni@umich.edu
}

Follow this and additional works at: https://repository.law.umich.edu/law_econ_current

Part of the Law and Economics Commons, and the Tax Law Commons

\section{Working Paper Citation}

Avi-Yonah, Reuven S. and Mazzoni, Gianluca, "Tit for Tat: How Will Other Countries React to the Tax Cuts and Jobs Act?" (2017). Law \& Economics Working Papers. 145.

https://repository.law.umich.edu/law_econ_current/145

This Article is brought to you for free and open access by University of Michigan Law School Scholarship Repository. It has been accepted for inclusion in Law \& Economics Working Papers by an authorized administrator of University of Michigan Law School Scholarship Repository. For more information, please contact mlaw.repository@umich.edu. 
DRAFT $12 / 21 / 17$

Tit for Tat:

Tit for Tat: How Will Other Countries React to the Tax Cuts and Jobs Act?

\author{
Reuven Avi-Yonah and Gianluca Mazzoni \\ The University of Michigan
}

The tax reform act of 1986 (TRA86) triggered significant tax reforms in other countries aimed at reducing the corporate tax rate while expanding the tax base. After the US cut its corporate tax rate from $46 \%$ to $34 \%$ in 1986, US trading partners in Europe began reducing their corporate tax rate from the $40-50 \%$ range to the 20 $30 \%$ range. This reduction in foreign tax rates became a major rationale for the current tax reform legislation (TRA17), which highlights cutting the corporate tax rate from $35 \%$ to $21 \%$.

What will be the effects of TRA17 in Europe, and how will the EU respond? There are several areas of TRA17 that are likely to have an effect on Europe and trigger a response.

\title{
1. Corporate tax rates.
}

TRA17 cuts the statutory corporate tax rate to $21 \%$. This by itself is only a bit lower than the OECD average $(25 \%)$ and is therefore unlikely to trigger a major reaction, although some further EU tax rate cutting can be expected.

However, TRA17 also adopts a temporary expensing provision that has the effect of reducing the effective corporate tax rate on normal returns to capital to zero. Another provision of TRA17 (the "patent box") cuts the corporate tax rate on income from exported intangibles to $13.125 \%$. The expensing provision can attract tangible investment into the US while the patent box can encourage shifting of intangible profits into the US.

Both provisions may alarm major EU countries because they would be concerned about losing jobs and revenue. One possible reaction would be a race to the bottom in which they adopt similar rules, like the UK has already begun to do (reducing its corporate tax rate below $20 \%$ and adopting a $10 \%$ patent box). But our larger trading partners, like France, Germany and Italy, are more likely to react by imposing their CFC rules on US subsidiaries of their own multinationals investing into the US. Under those rules, if the US effective tax rate is low enough, a deemed repatriation of the profit is triggered and it is taxed to the foreign parent. Importantly, the Anti-Tax Avoidance Directive requires all EU members to adopt CFC rules by 2019, and there are no limits on applying such rules to non- EU subsidiaries (like there are inside the EU). 
In addition, the patent box provision is a blatant violation of the WTO rules against subsidies that are contingent on exporting goods. The EU can be expected to challenge such rules in the WTO like it challenged earlier US export subsidies, and it is likely to win. The likely result will be that the US will be forced to abandon the patent box under threat of sanctions.

\section{The participation exemption}

TRA17 exempts income from controlled foreign corporations (CFCs) that is repatriated to their US parents if it is not Subpart F income. This is similar to the participation exemption of our major trading partners. The participation exemption does not apply if the payment is deductible at source, so it only applies to dividends that are treated as such by the source jurisdiction, not to interest or royalties.

The participation exemption is likely to exacerbate tax competition because US multinationals will know that the income can be repatriated tax free and will therefore shift more income to foreign jurisdictions with a rate below $21 \%$. The extent of double non-taxation will, however, be limited by the GILTI provision discussed below. In addition, it is possible that source countries will continue to exempt income while it is invested in them but will impose corporate tax upon repatriation, like Israel did to Intel. There will be no foreign tax credit in the US for such taxes, and they will not violate treaties because they are a corporate tax, not a withholding tax on the dividend.

\section{GILTI}

TRA17 imposes current tax with foreign tax credits on income of CFCs above a threshold amount based on tangible investment. The effect will be to encourage outbound job migration, which EU countries (especially low tax ones) will welcome. The fact that GILTI operates as a minimum tax with cross crediting may induce foreign tax rates to rise because it is possible to average tax credits across countries and thus escape GILTI. For example, if a US multinational has a CFC earning 100 subject to zero tax it can earn another 100 in another country subject to an effective tax rate of $26.25 \%$ and the resulting foreign tax credit for $80 \%$ of 26.25 , or 21 , will eliminate any GILTI liability, resulting in a final foreign tax of 26.25 , compared to a total tax of 31.5 for a similar investment in the US (21 in the US and 10.5 tax on GILTI).

\section{Base erosion}

TRA17 includes base erosion provisions (the "Base Erosion Anti-Abuse Tax", or BEAT) that go far beyond what the US has done in the past. The provision probably does not violate WTO rules because it mostly applies to interest and royalty payments and excludes inventory imports (it does apply to imports of depreciable goods from a related party, but this by itself may be rare enough not to trigger a WTO violation). The BEAT is also careful not to violate tax treaties, because formally 
it is neither a withholding tax on royalties and interest (violating articles 11 and 12) nor a denial of a deduction (violating article 24). Still, European countries are likely to view the BEAT as a de facto violation of the treaties because it is economically equivalent to denying the deduction in part. But there is little they can do about it short of terminating the treaties, because the savings clause (article 1(4)) and the ability to override treaties protect the US from a legal challenge, and the US will not subject itself to arbitration even if the result is double taxation, because US trading partners will not credit the BEAT. Like the UK Diverted Profits Tax, the likely outcome is that our trading partners will copy the BEAT and apply it to US multinationals.

\section{Conclusion}

In general EU countries may take steps to negate the competitive advantage gained by the US from the lower rate, expensing and the patent box. They may also take advantage of the participation exemption and GILTI to increase taxes on US multinationals. Finally, they are likely to copy the BEAT and apply it to US multinationals. 